\title{
Aviation hazards from volcanoes: the state of the science
}

\author{
A. J. Prata $\cdot$ A. Tupper
}

Received: 22 April 2009/Accepted: 22 April 2009/Published online: 4 July 2009

(C) Springer Science+Business Media B.V. 2009

The hazards wrought on society by volcanoes have been studied, discussed and reported extensively. Danger from volcanoes can occur on the land, on the sea and as this Special Issue highlights, in the air as well. The great eruptions of Vesuvius in AD 79 (Etienne 1992), Pelé in 1902 (Fisher and Heiken 1982) and Krakatau in 1883 (Self and Rampino 1981) caused widespread devastation and killed thousands of people. During the eruption of Vesuvius, the town of Pompeii was destroyed by pyroclastic flows and the mummified remains of some of the inhabitants bear testament to the dangers and rapidity of volcanic hazards. It is reported that 36,000 people lost their lives in the aftermath of the climactic eruption of Krakatau; many of these unfortunate people were killed by the tsunamis that followed the collapse of several $\mathrm{km}^{3}$ of rock into the sea. Shipping was particularly vulnerable during the eruptions of Krakatau and continued to suffer for more than 1 year following the major eruption. Atmospheric hazards from eruptions have also been studied, and a good example of the consequences of sustained eruptive activity on society is the 1763 Laki fissure eruption. Over a period of several months, the Laki eruption generated sufficient quantities of hazardous gases $\left(\mathrm{SO}_{2}, \mathrm{HCl}\right.$ and $\left.\mathrm{HF}\right)$ to kill more than $50 \%$ of the Icelandic livestock and severely affected the health and well-being of the population (Thordarson et al. 1996). Impacts on human health from several different volcanic eruptions are described by Baxter (2005). Societal vulnerability and risk from volcanic eruptions on land, on the sea and in the atmosphere are serious (Blong 1984)—considerable resources are expended to guard against and respond to these hazards. In the modern era, since the introduction of transcontinental air travel, a new threat from volcanoes has emerged: volcanic ash in the upper troposphere, where jet aircraft fly, can cause jet engine failure (loss of power), damage to turbine blades and pitot static tubes, with the possibility of the loss of the aircraft and lives (Casadevall et al. 1996). The increase in passenger air traffic (growing at an average of 5\% per year, globally) (ESCAP 2005) coupled with the

A. J. Prata (凶)

Norwegian Institute for Air Research, P.O. Box 100, 2027 Kjeller, Norway e-mail: fpr@nilu.no 
inherent unpredictability of volcanic eruptions make this relatively new volcanic hazard a significant threat to society.

There has been a series of symposia and workshops addressing the problem of volcanic hazards to aviation, the first one of these was held in Seattle, Washington in 1991 following the major eruption of Pinatubo. The papers from that symposium were published by the USGS (Casadevall 1994a). Thirteen years later, a second symposium was held- “"The 2nd International Conference on Volcanic Ash and Aviation Safety" (OFCM 2004) in Alexandria, Virginia, USA. In between these meetings, an important reference work was published in the Encyclopedia of Volcanoes by Miller and Casadevall (2000), and several regional and topical meetings were held in Australia, Japan, Alaska and France. The focus of these meetings has always been on improving ways to help aviation avoid hazardous volcanic clouds. The current operational regime for disseminating volcanic ash hazard warnings to aviation divides the world into nine regions (see Fig. 1), each with a Volcanic Ash Advisory Centre (VAAC) sited within a national meteorological agency. Since the governance of warnings for other aviation hazards (e.g. turbulence, severe weather, icing) falls within the responsibility of meteorological agencies, it is natural and appropriate that volcanic hazard warnings reside there too.

This Special Issue represents a scholarly attempt to describe and synthesise our current knowledge concerning the threat of volcanic hazards on aviation and grew out of a Volcanic Ash and Aviation Workshop held in the volcanic region of Rotorua, New Zealand in March 2007. The meeting was organised by the World Meteorological Organisation (WMO) in conjunction with the International Civil Aviation Organisation (ICAO). The workshop brought together representatives from the aviation industry, government, aviation authorities (ICAO, FAA and the CAA), volcanological and geological agencies (e.g. the USGS), and academics to discuss and report on progress with methods and procedures aimed at assisting aviation in the avoidance of volcanic hazards.

The major hazard from volcanic eruptions to aviation is volcanic ash, and this was first properly recognised and documented following a well-publicised incident involving a British Airways jet and a volcanic cloud from an eruption of Galunggung volcano in Indonesia in 1982. The aircraft lost power to all engines and reportedly dropped more than 12,000 feet before power could be restored to three engines and an emergency landing made at Jakarta. At the time, the crew and passengers had no idea what had caused this nearly catastrophic event. Examination of the engines and air-frame later confirmed that the aircraft had entered an ash cloud. The aircraft radar, visual systems and conventional meteorological analyses had all failed to warn the aircraft of the impending danger (Johnson and Casadevall 1994). Another major incident involving a KLM 747 jet en route from Amsterdam to Anchorage, Alaska, occurred in 1989. This aircraft encountered an ash cloud from Redoubt volcano. Despite knowledge of the eruption, reports of the locations of the ash clouds and procedures in place for avoidance, the aircraft suffered loss of engine power, and engine damage costing many millions of dollars (Casadevall 1994b). More than 40 separate aviation incidents occurred during the Pinatubo eruptions in June 1991 (Casadevall et al. 1996). Events like these, while still relatively rare, caused sufficient alarm to stimulate the research community into thinking about, and devising ways to detect ash clouds. They also stimulated government agencies and aviation authorities into developing a global warning system based on 'best practice' use of technology and a universally accepted set of procedures and advisories to follow in the event of an encounter with an ash cloud.

The nature of the problem can be seen from Fig. 2, which shows the distribution of Holocene volcanoes and a list of the most recent volcanoes that have erupted causing 


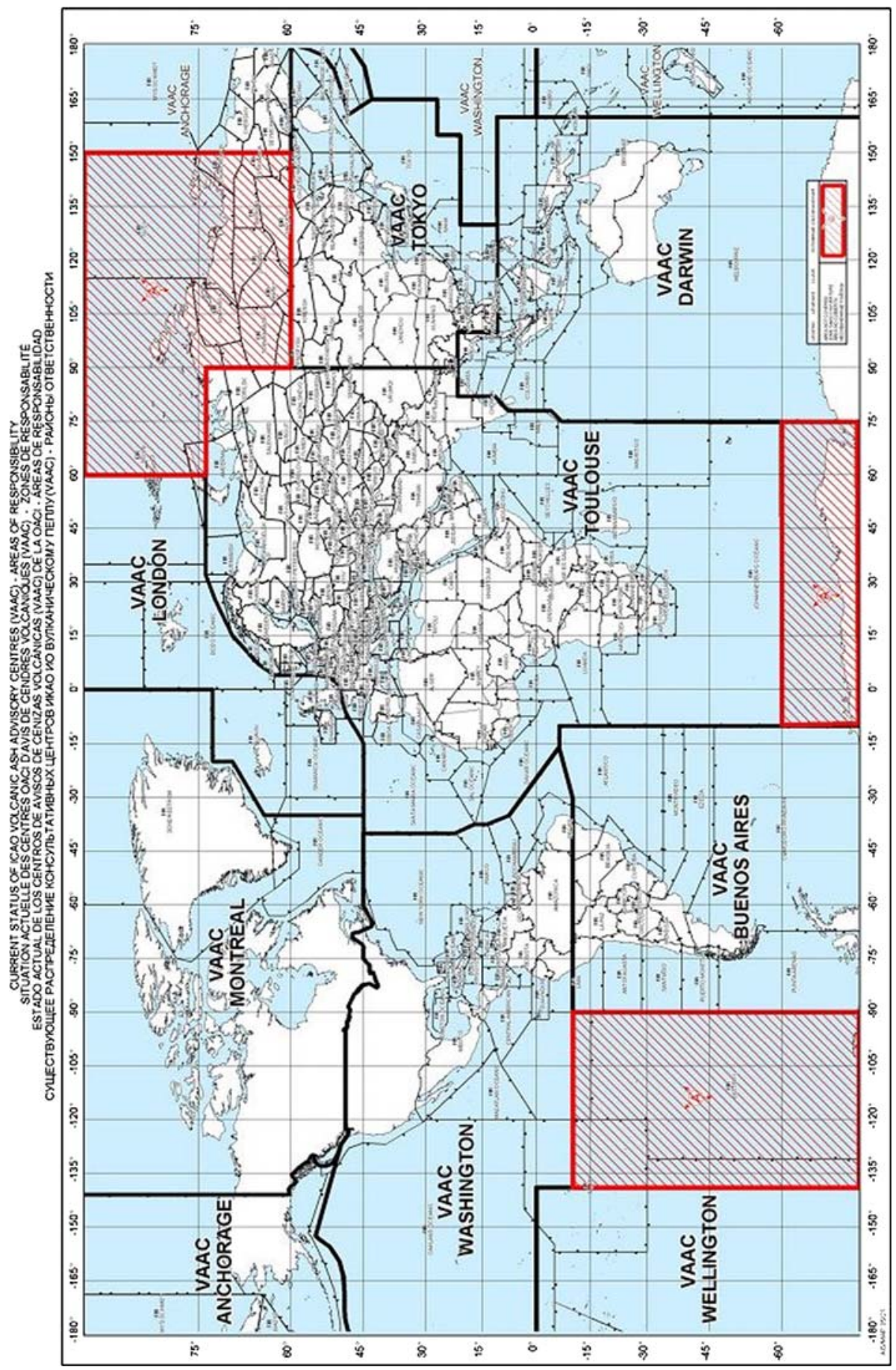

Fig. 1 Map showing the regions of responsibility of the nine Volcanic Ash Advisory Centres (VAACs) 


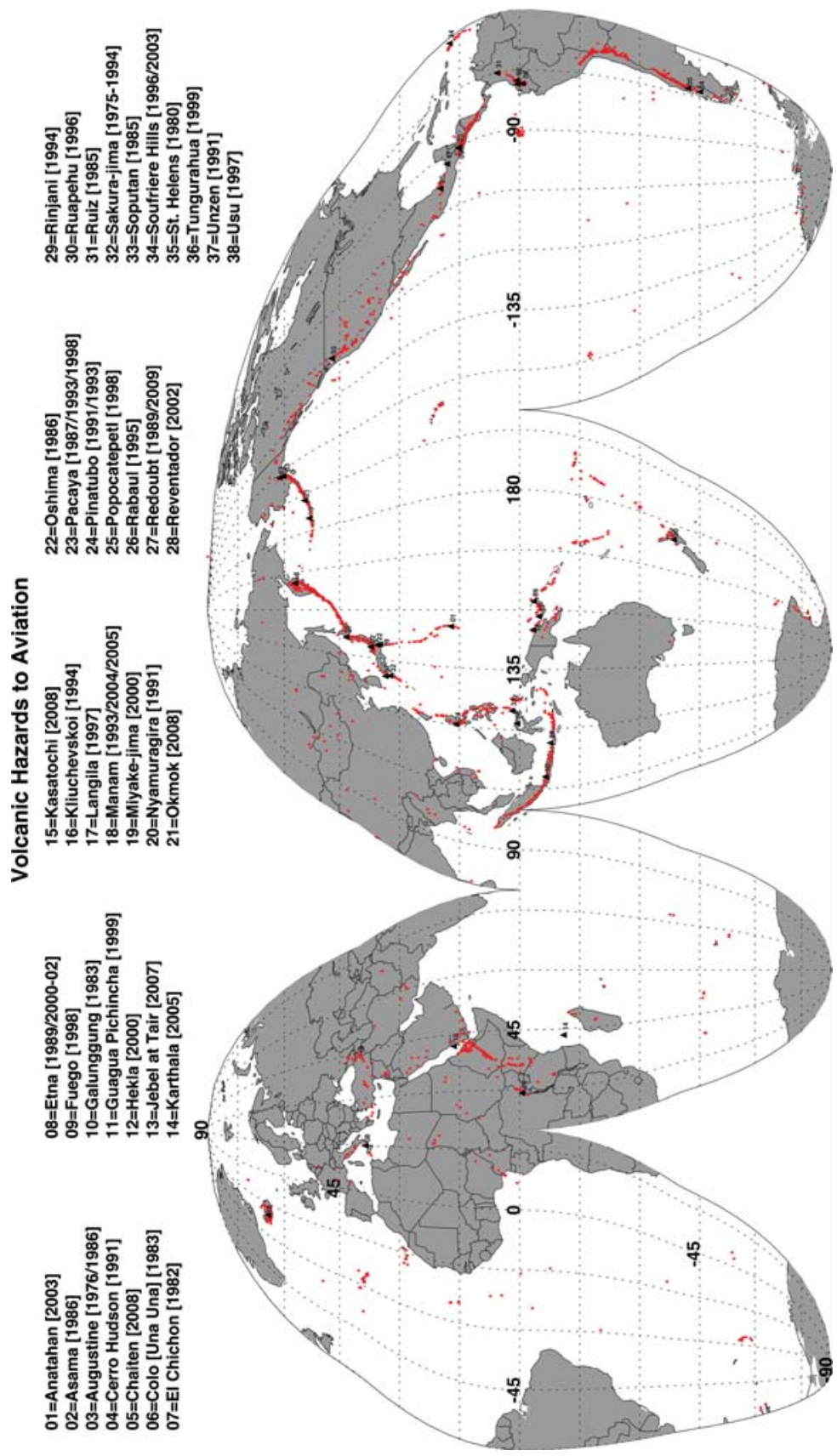

Fig. 2 Locations of Holocene volcanoes (red triangles) and the most recent volcanoes that have emitted ash and gas causing aviation problems based on the study of Guffant et al. (2004) and ICAO (2001). The years when an aviation incident occurred are indicated for each volcano 
problems to aviation (an update based on the study of Guffanti et al. 2004). The problem stems from the inherently unpredictable nature of volcanic activity, the ability of the earth's wind circulation systems to spread ash and gas over large distances quickly and the difficulty associated with managing the highly complex and vital aviation business. Of prime importance is the protection of lives, but for aviation to be cost effective and profitable, it is also important for the industry to mange risks and seek economical solutions. Thus, it is not practical, for example, to ground aircraft because of the real or envisaged threat of a volcanic eruption. Re-routing is a more sensible action, but this carries an economic cost, and a strategy must be developed by each carrier to manage risk and weigh this against safety concerns and the economic cost. The hazard to aviation is not only confined to air traffic. Significant danger and concomitant cost occur from ash-fall at airports and on runways in regions vulnerable to volcanic activity (Fig. 3).

There are nine articles in this Special Issue. Three articles concentrate on the regional responses and preparedness to volcanic hazards in Russia (Neal), in New Zealand and SW Pacific (Scott), and in the USA (Albersheim and Guffanti). One article (Guffanti et al.) focusses on the hazard to airports showing how this is a significant and growing problem all over the world, with more than 100 airports at risk from volcanic hazards. The article by Prata reviews remote-sensing techniques for detecting ash clouds, describes the successes and problems and looks into the future to assess the risk to global air traffic in an era of increasing commercial travel. Carn et al. discusses the state of the art of satellite tracking $\mathrm{SO}_{2}$ emissions from volcanoes, highlighting the measurements from the Ozone Monitoring Instrument (OMI), a new addition in the arsenal of sensors now being applied to the detection of volcanic clouds. Visualisation of dispersion model and satellite data is of great importance in communicating accurately and efficiently the spatial structure of volcanic hazards. Webley et al. show how this can be done using the latest methods in computer animation utilising Virtual Globes and Google Earth. There are two articles that deal with the complexities of ash cloud dynamics. Rose and Durrant study the fallout from the major

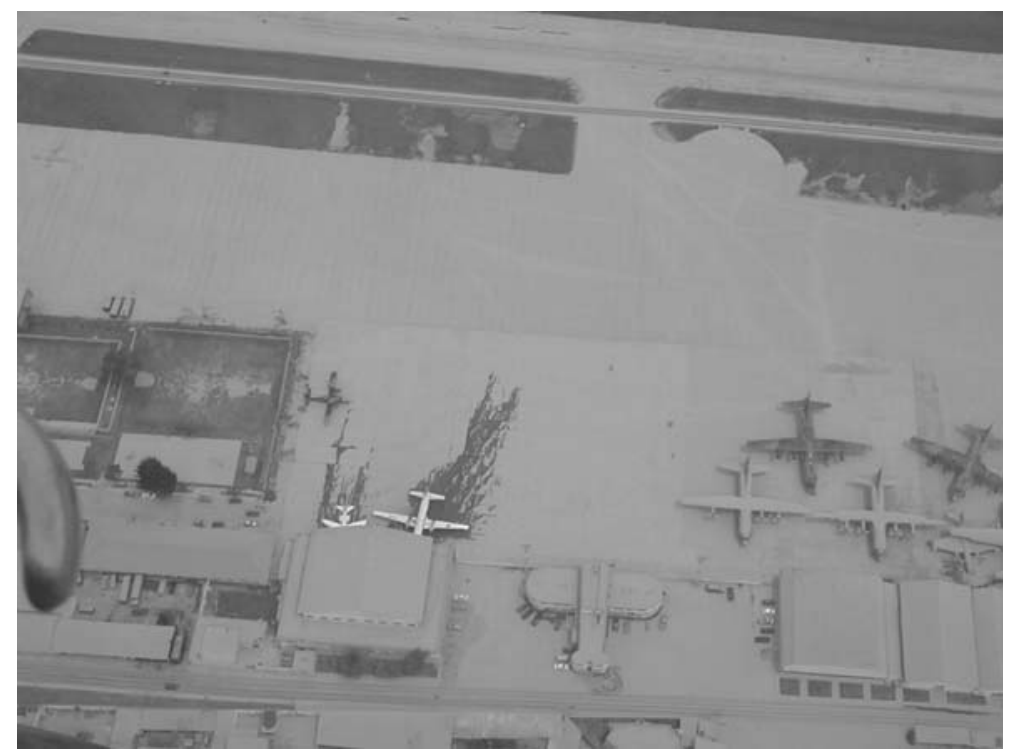

Fig. 3 Quito airport after ash-fall from Gua Gua Pichincha volcano 
eruption of El Chichón in 1982. The existence of fine particles in volcanic eruption clouds constitutes the main hazard to jet aircraft, and so the processes affecting the fate of these particles are of great interest. Due to convective currents in clouds and nucleation of ice by fine ash, many small particles $(<62 \mu \mathrm{m}$ in diameter) fall out sooner than otherwise. The final article by Tupper et al. investigates the eruption height and subsequent ash fallout using a high-resolution atmospheric model, specifically designed to simulate the behaviour of erupting volcanic columns. Important inferences on the effects of hydrometeors on fine ash are drawn from the study with repercussions for remote sensing of ash clouds.

The articles in this Special Issue cover many of the important topics associated with the volcanic ash-aviation hazard and provide in one place a comprehensive resource describing the state of the science.

\section{References}

Baxter P (2005) Human impacts of volcanoes. In: Martí J, Ernst GGJ (eds) Volcanoes and the environment. Cambridge University Press, Cambridge, pp 273-303

Blong RJ (1984) Volcanic hazards: a sourcebook on the effects of eruptions. Academic Press, Sydney Australia

Casadevall TJ (eds) (1994a) Volcanic ash and aviation safety. In: Proceedings of the first international symposium, Seattle, Washington, July 1991, U.S. Geological Survey Bulletin B 2047, pp 450. http://www.dggs.dnr.state.ak.us/pubs/pubs?reqtype=citation $\& I D=376$

Casadevall TJ (1994b) The 1989-1990 eruption of Redoubt Volcano, Alaska: impacts on aircraft operations. J Volcanol Geotherm Res 62:301-316

Casadevall TJ, Delos Reyes PJ, Schneider DJ (1996) The 1991 Pinatubo eruptions and their effects on aircraft operations. In: Newhall CG, Punongbayan RS (eds) Fire and Mud: eruptions and lahars of Mount Pinatubo, Philippines. Philippines Institute of Volcanology and Seismology/University of Washington Press, Quezon City/Seattle, pp 625-636

ESCAP (2005) Review of developments in transport in Asia and the Pacific 2005. United Nations Publication No. E.06.II.F.9, ST/ESCAP/2392. 172 pp

Etienne R (1992) Pompeii: the day a city died. Harry N. Abrams Inc./Thames and Hudson Ltd., New York/ London, $215 \mathrm{pp}$

Fisher RV, Heiken G (1982) Mt Pelée, Martinique: May 8 and 20, 1902, pyroclastic flows and surges. J Volcanol Geotherm Res 13:339-371

Guffanti M, Casadevall TJ, Mayberry G (2004) Reducing encounters of aircraft with volcanic-ash clouds. In: Second international conference on volcanic ash and aviation safety. Alexandria, Virginia, USA, pp $1 / 17-21$

International Civil Aviation Organization (2001) Manual on volcanic ash, radioactive material and toxic chemical clouds. ICAO Doc 9766-AN/954(Montreal), pp I-2-6-I-2-7

Johnson RW, Casadevall TJ (1994) Aviation safety and volcanic ash clouds in the Indonesia-Australia region. In: First international symposium on volcanic ash and aviation safety. Seattle, Washington, USA, pp 191-197

Miller TP, Casadevall TJ (2000) Volcanic ash hazards to aviation. In: Sigurdsson H (ed) Encyclopedia of Volcanoes. Academic Press, San Diego, pp 915-930

OFCM (2004) Proceedings of 2nd international conference on volcanic ash and aviation safety, Alexandria, Virginia (USA), 21-24 June 2004 . U.S. Department of Commerce/National Oceanic and Atmospheric Administration. http://www.ofcm.gov/ICVAAS/Proceedings2004/ICVAAS2004-Proceedings.htm

Self S, Rampino MR (1981) The 1883 Krakatau eruption. Nature 294:699-704

Thordarson T, Self S, Okarsson N (1996) Sulfur, chlorine, and fluorine degassing and atmospheric loading by the 1783-1784 AD Laki (Skaftár Fires) eruption in Iceland. Bull Volcanol 58:205-225 